\title{
TOTOBUANG
}

\begin{tabular}{lll}
\hline Volume 9 & Nomor 2, Desember 2021 & Halaman 301-313
\end{tabular}

\section{IDENTITAS SOSIAL DAN KEARIFAN LOKAL PADA KUMPULAN CERPEN CELURIT HUJAN PANAS KARYA ZAINUL MUTTAQIN (Social Identity and Local Wisdom in The Collection of Short Stories Celurit Hujan Panas By Zainul Muttaqin)}

\author{
Bayu Suta Wardianto \\ Universitas Muhammadiyah Purwokerto \\ Jl. K.H. Ahmad Dahlan, Dukuhwaluh, Kabupaten Banyumas, Jawa Tengah 53182 \\ Pos-el: sutasartika@gmail.com
}

Diterima: 12 Agustus 2021; Direvisi: 30 November 2021; Disetujui: 7 Desember 2021

doi: https://doi.org/10.26499/ttbng.v9i1.323

\begin{abstract}
Social society and socio-culture cannot be separated from each other. Therefore, literature was born as a product of society and culture. From these literary works, literary teaching materials with social and cultural background can be made. This study explains the social identity and local wisdom contained in the collection of Celurit Hujan Panas short stories by Zainul Muttaqin. In this study, the method used is the quality desriptive method. The data used comes from quotes on a collection of short stories of Celurit Hujan Panas. This research used listening and note-taking techniques. Research data analysis started from presenting the data, reducing the data, and analyzing conclusions. The results of this study show that the social identity contained in the story are namely (1) social structure, (2) social behavior, and (3) ontological definitions. Moreover, the values of local wisdom contained in the story are (1) culture, (2) beliefs, and (3) social values.

Keywords: social identity, local wisdom, a collection of short stories of celurit hujan panas.
\end{abstract}

\section{Abstrak}

Sosial masyarakat dan sosial budaya tidak bisa dipisahkan satu sama lain. Karena itulah, sastra lahir sebagai produk dari sosial dan budaya. Dari karya sastra tersebut, dapat dibuat bahan ajar sastra berlatar sosial dan budaya. Penelitian ini menjelaskan tentang identitas sosial dan kearifan lokal yang terkandung dalam kumpulan cerpen Celurit Hujan Panas karya Zainul Muttaqin. Metode yang digunakan dalam penelitian ini yaitu metode deksriptif kualititatif. Data yang digunakan berasal dari kutipan pada kumpulan cerpen Celurit Hujan Panas. Penelitian menggunakan teknik simak dan catat. Analisis data penelitian dimulai dari menyajikan data, mereduksi data, dan kesimpulan analisis. Penelitian ini menunjukkan hasil bahwa identitas sosial yang terkandung yaitu (1) struktur sosial, (2) tingkah laku sosial, dan (3) definisi ontologis. Nilai kearifan lokal yang terkandung adalah (1) nilai budaya, (2) kepercayaan, dan (3) nilai sosial.

Kata-kata kunci: identitas sosial, kearifan lokal, kumpulan cerpen celurit hujan panas.

\section{PENDAHULUAN}

Sastra, masyarakat, dan keadaan sosial adalah tiga komponen yang tidak bisa dipisahkan. Sastra ada karena hasil dari buah keterampilan dan produk budaya yang dihasilkan oleh masyarakat dalam kehidupan sosialnya. Sastra tumbuh dan berkembang dalam pusaran arus budaya yang ada di masyarakat. Karena itulah, karya sastra tidak akan jauh dari permasalahan tentang sosial masyarakat dan budaya yang terdapat pada kehidupan bermasyarakat. Dengan demikian muncul simpul antara sosial masyarakat, budaya, dan sastra yang saling berkaitan. Jika sosial masyarakat dan kebudayaan yang berkembang adalah proses, maka sastra adalah hasil dari proses kreatif perkembangan budaya dan sosial.

Karya sastra bisa juga dipahami sebagai hasil atau buah dari penginderaan 
penulis (manusia) terhadap suatu realita yang ada kemudian menuangkannya dalam media bahasa baik lisan ataupun tulisan, sehingga hasil tersebut dapat dibaca atau dipelajari. Karya sastra tersusun dari seperangkat tanda atau simbol yang memiliki arti dalam konvensi tertentu.

Sebuah karya sastra yang lahir dalam sebuah kebudayaan dan realita sosial yang ada dipengaruhi oleh percampuran bidang ilmu yang lain. Dalam kaitannya dengan cabang ilmu, sosiologi dan antropologi adalah ilmu yang membahas tentang kemasyarakatan dan kebudayaan. Baik sosiologi maupun antropologi sama-sama membahas tentang manusia. Sosiologi memandang manusia melalui kehidupan sosial kemasyarakatan dan proses-proses sosial yang terjadi, sedangkan antropologi memandang manusia melalui kebiasaan, perilaku, dan kebudayaannya.

Sosiologi dan antropologi yang memengaruhi karya sastra, akhrinya memunculkan sebuah pandangan baru yang bernama sosiologi sastra dan antroplogi sastra. Kedua istilah tersebut mengacu kepada penggabungan antara sastra yang mengandung unsur kemasyarakatan dan sastra yang mengandung unsur kebudayaan. Pengaruh dari sosiologi sastra dan antropologi sastra ini membuat sebuah karya sastra mempunya ciri khasnya tersendiri. Dari sosiologi sastra terdapat beragam pendekatan atau model yang ditemukan, misalnya identitas sosial yang ada dalam karya sastra.

Selain pengaruh sosiologi sastra yang menghasilkan identitas sosial, antropologi sastra juga mempunyai banyak turunan atau model yang terkandung di dalamnya, salah satunya adalah mengenai kearifan lokal. Contoh atau penggambaran tentang adanya kearifan lokal dalam karya sastra ini terkandung dalam cerita-cerita sastra yang menggambarkan kebudayaan pada suatu kelompok masyarakat tertentu, misalnya penggambaran tentang budaya santet atau teluh sebagai kekhasan budaya Banten yang disinggung dalam novel Balada Si Roy yang ditulis oleh Gol A Gong.

Identitas sosial dan kearifan lokal ini menjadi sebuah kekhasan tersendiri yang terkandung dalam sebuah karya sastra. Dari banyaknya ragam dan jenis karya sastra, cerpen merupakan salah satu jenis karya sastra yang dapat dipilih dan digunakan untuk menjelaskan identitas sosial dan kearifan lokal yang ada. Salah satu cerita pendek yang di dalamnya terkandung nilai identitas sosial dan kearifan lokal ini adalah kumpulan cerpen yang berjudul Celurit Hujan Panas karya Zainul Muttaqin (2019). Kumpulan cerpen ini berisikan 20 cerita pendek yang menceritakan tentang kisah sehari-hari berlatarkan pulau garam atau Madura yang berisikan tentang kejadiankejadian sosial serta adat-istiadat dan budaya Madura yang terkenal seperti karapan sapi dan juga carok.

Kumpulan cerpen Celurit Hujan Panas karya Zainul Muttaqin ini nantinya akan dilakukan penganalisisan terhadap unsur identitas sosial dan unsur kearifan lokal yang terkandung di dalamnya. Sebagai pembanding dengan penelitian yang sudah ada kumpulan cerpen Celurit Hujan Panas karya Zainul Muttaqin pernah dikaji oleh Farida dan Andalas (2019) dengan judul Eksistensi Kearifan Lokal Madura di Era Modern dalam Celurit Hujan Panas Karya Zainul Muttaqin. Pada penelitian ini, Farida dan Andalas mengkaji bagaimana unsur kearifan lokal yang terkandung serta menghubungkannya dengan kenyataan pada era modern. Selain itu, pengkajian terhadap objek yang sama juga ditemukan pada penelitian yang ditulis oleh Miftakhul Jannah (2019) yang berjudul Hegemoni Kekuasaan pada Masyarakat Madura dalam Kumpulan Cerpen Celurit Hujan Panas Karya Zainul Muttaqin. Penelitian ini menjelaskan tentang struktur kelas sosial yang ada pada kumpulan cerpen Celurit Hujan Panas karya Zainul Muttaqin. 
Penelitian yang peneliti lakukan ini merupakan pembaruan, karena membahas perihal identitas sosial dan kearifan lokal dari kumpulan cerpen Celurit Hujan Panas karya Zainul Muttaqin sebagai suatu penggabungan antara pengkajian sosiologi sastra dan antropologi sastra.

\section{LANDASAN TEORI}

Karya sastra merupakan hasil dari keterampilan atau kegiatan kreatif yang didasari oleh ekspresi manusia sehingga menghasilkan sebuah karya berupa tulisan maupun lisan yang bernilai seni atau keindahan yang menggambarkan tentang imaji dari kehidupan yang ada (Sumardjo \& Saini, 1986; Wellek \& Warren, 2016; Winarni, 2009). Karya sastra bisa juga dimengerti sebagai buah dari penginderaan penulis (manusia) terhadap realita yang ada kemudian menuangkannya dalam media bahasa baik lisan ataupun tulisan sehingga hasil tersebut dapat dibaca atau dipelajari. Karya sastra tersusun dari seperangkat tanda atau simbol yang memiliki arti dalam konvensi tertentu. Karya sastra merupakan bentuk sebuah keterampilan yang berisikan sesuatu yang bersifat fiktif, imajinatif, dan artistik berdasarkan luapan emosi dan pengalaman batin yang terjadi pada penulis (manusia) dengan menggunakan medium bahasa (Jari, 2016; Ratna, 2004).

\section{Cerita Pendek}

Cerita pendek adalah bagian dari karya fiksi nonfaktual yang artinya adalah buah imajinasi pengarang yang tidak semuanya mengemukakan fakta dan data akan tetapi tetap mempunyai makna dan menjunjung tinggi kebenaran (Sapdiani dkk., 2018). Pada cerpen, unsur penokohan ditekankan kepada satu orang, peristiwa khas dan latar yang berjalan menjadi gambaran dari cerita yang disampaikan, dan dengan penutup atau akhiran yang menyampaikan makna dari cerita tersebut (Rampan, 2013: 98). Cerpen memfokuskan cerita hanya pada satu tema dan fokus ke dalam satu tokoh saja. Tema dan alurnya pun tidak rumit dan tidak membuat pembaca bingung. Pada satu cerpen hanya akan ada satu tokoh sentral dengan satu tema yang melingkupinya.

Cerpen juga dapat diartikan sebagai cerita fiktif yang tidak betul-betul terjadi, namun bisa terjadi di mana pun dan kapan pun, serta relatif pendek (Sumardjo \& Saini, 1986: 37). Selain itu, cerpen berbeda dengan puisi secara instrinsik dengan tidak adanya penokohan di dalamnya. cerpen akan menjadi menarik karena ketergantungannya pada unsurunsur yang ada pada cerpen tersebut, salah satunya terdapat penokohan yang dikonstruksi oleh pengarang. Dengan adanya rekonstruksi tokoh dengan usur lain, pengarang bisa menyampaikan pesan berupa perenungannya terhadap sebuah peristiwa atau hakikat hidup (Muhammad dkk., 2018).

Maka dari itu, dapat disimpulkan bahwasanya cerpen merupakan cerita atau karangan fiktif yang menceritakan kehidupan seseorang atau sesuatu yang melibatkan tentang kehidupannya yang di dalamnya terdapat unsur sosial, politik, ekonomi, agama dan budaya yang ditulis secara rinci serta ringkas dengan satu tokoh sentral dan tema umum yang melingkupinya, namun tetap memiliki pesan dan pemaknaan.

\section{Sosiologi Sastra}

Sosiologi berartikan ilmu tentang atau sejarah atau yang mengenai asal-usul dari pertumbuhan dalam masyarakat, yang juga mempelajari tentang beragam jenis jaringan hubungan yang ada pada manusia dalam masyarakat (Ratna, 2009). Sosiologi sastra dapat juga dikatakan sebagai penggabungan antara dua disiplin ilmu yang berbeda namun saling berkaitan. Istilah tersebut mengacu kepada penggabungan antara sastra sebagai sesuatu yang mengandung realita sosial yang terjadi pada kehidupan bermasyarakat. Selanjutnya, sosiologi sastra merupakan pemahaman terhadap karya sastra yang di dalamnya menyangkut status sosial, ideologi sosial, dan mempertimbangkan aspek-aspek kemasyarakatan (Faruk, 2005; Ratna, 2009). 


\section{Identitas Sosial}

Identitas sosial yang terkandung dalam karya sastra membicarakan tentang konsep individu yang memiliki pengetahuan tertentu mengenai anggota yang terdapat dalam suatu kelompok sosial tertentu yang sudah tertanam secara emosional dalam kelompok tersebut (Ashmore, et all., 2001). Sejalan dengan pendapat tersebut, Doise juga menyebutkan bahwa identitas sosial merupakan penggambaran sosial dari beragam individu dalam suatu kelompok sosial serta mempunyai emosi dan pandangan yang sama (Doise, 1998).

Identitas sosial berbicara tentang sebuah perlakuan sosial antaranggota individu yang berasal dari suatu kelompok yang sama dan juga sebagai perbandingan individu (dirinya) serta kelompok dengan yang lainnya (Nawawi, 2017). Maksudnya adalah, individu yang terdapat pada suatu kelompok sosial masyarakat tertentu pastilah mempunyai sebuah pandangan atau emosi yang sama. Misalnya ketika suatu individu dari kelompok suku Jawa sedang menggelar kenduri, maka otomatis kelompok lainnya akan membantu atau setidaknya terlibat dalam berbagai peran yang ada pada kegiatan tersebut. Identitas sosial dalam karya sastra ini menandakan bahwa manusia memang tidak bisa terlepas dari kontrol sosial kelompok masyarakat yang sudah tertanam dan mengakar pada sebuah peraturan yang tidak tertulis namun berlaku. Giddens (1991) mengklasifikasikan identitas sosial menjadi (1) struktur sosial, (2) tingkah laku sosial, dan (3) definisi ontologis.

\section{Antropologi Sastra}

Antropologi dijelaskan sebagai suatu ilmu yang mengkaji perihal manusia serta masyarakat, baik yang terjaga (masih ada) ataupun juga yang telah tiada atau sudah mati, yang berproses dan berkembang maupun yang telah punah atau tiada berdasarkan sistem atau tatanan kehidupan yang telah berlangsung secara terus-menerus (Coleman and Watson, 2005). Kaitannya dengan sastra, antropologi sastra dapat dikatakan sebuah pemahaman atau pun juga pendekatan kajian terhadap suatu karya sastra yang ada keterkaitannya antara kehidupan manusia yang berkaitan dengan kebudayaan (Ratna, 2011).

\section{Kearifan Lokal}

Kearifan lokal berkaitan dengan gagasan, perilaku, dan aktivitas serta norma atau tata krama yang melingkupi dan menjadi kekhasan tersendiri dari masyarakat di suatu tempat (Kasmi, 2019). Sejalan dengan pengertian tersebut, Ahmad (2020) menjabarkan bahwa definisi "lokal" di sini tidak selamanya bersifat sederhana, sempit, rendah, dan bernilai peyorasi lainnya. Dalam banyak hal, kearifan lokal ini mampu menjadi pengantisipasi berbagai permasalahan yang terjadi.

Kearifan lokal juga dikenal dengan istilah pengetahuan lokal, baik kearifan lokal atau pengetahuan lokal merupakan bagian dari suatu kebudayaan lokal. Kearifan dan kebudayaan lokal hanyalah sebagian kecil dari intisari kebiasaan kelompok masyarakat tertentu (Ratna, 2011).

\section{METODE PENELITIAN}

Penelitian yang dilakukan oleh peneliti ini menggunakan metode penelitian yang diterapkan yaitu deksriptif kualitatif. Deskriptif kualitatif dalam penelitian menggunakan teknik analisis isi (content analysis) untuk mengkaji unsur identitas sosial dan kearifan lokal yang terdapat pada kumpulan cerpen Celurit Hujan Panas. Metode ini diterapkan guna memecahkan masalah atau menjawab permasalahan yang tersaji secara kompleks atau yang aktual dengan cara mengumpulkan, menyusun, mengklarifikasi, menganalisis, dan menginterpretasi (Ratna, 2007). Deskriptif merupakan metode atau jenis penelitian yang dilakukan berdasarkan fakta dan fenomena yang dilakukan dengan pengamatan terhadap sumber data, sehingga menghasilkan hasil berupa kata-kata atau narasi yang bersifat memaparkan (Sugiyono, 2011). Objek 
penelitian pada penelitian ini yaitu buku kumpulan cerpen Celurit Hujan Panas karya Zainul Muttaqin terbitan Gramedia Pustaka Utama, tahun 2019, cetakan pertama.

Teknik pengumpulan data yang dilaksanakan oleh peneliti yaitu dengan melakukan studi pustaka untuk mencari dan mengumpulkan bahan dan informasi dari kepustakaan yang berkaitan dengan objek yang diteliti (Faruk, 2012). Selanjutnya yang dilakukan oleh peneliti yaitu teknik simak, kegiatan pengumpulan data dari hasil simakan tulisan-tulisan yang berkaitan dengan objek penelitian. Kemudian yang terakhir yaitu teknik catat, guna menyimpulkan hasil pustaka dan menyimak dari objek yang diteliti.

Tahapan analisis pada penelitian ini yaitu dengan menerapkan tiga tahapan: (1) mengumpulkan data, (2) mereduksi data, dan (3) menyajikan data. Pada penelitian ini pengumpulan data dilakukan dengan menggali dan mencari kutipan berupa kalimat atau dialog yang mengandung unsur identitas sosial atau kearifan lokal yang nantiya akan menjadi data atau objek dalam penelitian ini. Langkah selanjutnya yang akan dilakukan yaitu reduksi data. Data akan direduksi sesuai kelompok berdasarkan klasifikasi atau jenis data yang sudah ditentukan. Setelah data terkumpul dan direduksi, maka data akan analisis sehingga menghasilkan sebuah gambaran atau penafsiran tentang identitas sosial atau kearifan lokal yang terkandung dalam kumpulan cerpen Celurit Hujan Panas karya Zainul Muttaqin.

\section{PEMBAHASAN}

Hasil analisis yang dilakukan pada penelitian ini yaitu terhadap kumpulan cerpen Celurit Hujan Panas dengan menggunakan dua pisau bedah berbeda yang menghasilkan dua unsur yang berbeda pula, sosiologi sastra dan antropologi sastra. Sosiologi sastra menghasilkan nilai-nilai identitas sosial, sedangkan antropologi sastra menghasilkan kearifan lokal yang ada dalam kumpulan cerpen tersebut.

Pada identitas sosial, nilai-nilai yang terkandung dalam kumpulan cerpen Celurit Hujan Panas karya Zainul Muttaqin meliputi (1) struktur sosial, (2) tingkah laku sosial, dan (3) definisi ontologis, sedangkan pada nilai kearifan lokal meliputi (1) nilai budaya, (2) kepercayaan, serta (3) nilai sosial.

Jumlah data penelitian yang mengandung nilai identitas sosial dan kearifan lokal kemudian akan ditampilkan dalam sebuah tabel data penelitian. Data tersebut diperoleh dari hasil teknik penelitian dan tahapan penelitian yang dilakukan terhadap objek yang yang diteliti. Dari pembacaan dan pencatatan yang dilakukan terhadap sumber data, maka terdapat hasil berupa data-data yang selanjutnya akan dijelaskan pada tabel berikut.

Tabel 1

Jumlah Data Penelitian

\begin{tabular}{|c|c|c|c|c|c|}
\hline No & $\begin{array}{c}\text { Nilai } \\
\text { Identita } \\
\text { S Sosial }\end{array}$ & $\begin{array}{c}\text { Jumla } \\
\mathbf{h} \\
\text { Data }\end{array}$ & $\begin{array}{c}\text { No } \\
\cdot\end{array}$ & $\begin{array}{c}\text { Nilai } \\
\text { Kearifan } \\
\text { Lokal }\end{array}$ & $\begin{array}{c}\text { Jumla } \\
\mathbf{h} \\
\text { Data }\end{array}$ \\
\hline 1 & $\begin{array}{c}\text { Struktur } \\
\text { Sosial }\end{array}$ & 7 & 1 & $\begin{array}{c}\text { Kebudayaa } \\
\text { n }\end{array}$ & 7 \\
\hline 2 & $\begin{array}{c}\text { Tingkah } \\
\text { Laku } \\
\text { Sosial }\end{array}$ & 12 & 2 & $\begin{array}{c}\text { Kepercaya } \\
\text { an }\end{array}$ & 9 \\
\hline $\begin{array}{c}\text { Definisi } \\
\text { Ontolog } \\
\text { is }\end{array}$ & 4 & 3 & $\begin{array}{c}\text { Nilai } \\
\text { Sosial }\end{array}$ & 6 \\
\hline & $\begin{array}{c}\text { Jumlah } \\
\text { Data }\end{array}$ & $\mathbf{2 3}$ & & $\begin{array}{c}\text { Jumlah } \\
\text { data }\end{array}$ & $\mathbf{2 2}$ \\
\hline
\end{tabular}

Identitas Sosial dalam Kumpulan Cerita Pendek Celurit Hujan Panas karya Zainul Muttaqin

Identitas sosial merupakan sebuah konsep yang menjelaskan bagaimana cara menilai identitas seseorang atau kelompok yang secara sosial tak terlepas daripada anggota masyarakat sosial yang lainnya (Hogg \& Abrams, 1988). Identitas sosial berupaya menjelaskan dan mengenal 
pemilahan serta penetapan bagi identitas seseorang dalam kelompoknya. Identitas sosial ini tidak dapat dilepaskan dari suatu individu masyarakat selama individu tersebut masih menjadi bagian dari suatu masyarakat tertentu.

Dalam pembagiannya terhadap penjelasan tersebut, klasifikasi identitas sosial terbagi menjadi (1) struktur sosial, (2) tingkah laku sosial, dan (3) definisi ontologis (Giddens, 1991).

\section{Struktur Sosial}

Struktur sosial atau yang bisa juga disebut kategori sosial merupakan landasan berperilaku atau berkelakuan bagi seseorang atau individu dalam proses menerapkan suatu ciri khas (identitas) yang mempunyai hubungan dengan kelompoknya. Seseorang tersebut biasanya dapat dikelompokkan dalam kategori umur, jenis kelamin, ras, etnik, budaya, serta yang lainnya (Giddens, 1991). Suatu invidu dapat dikatakan menjadi anggota suatu kelompok masyarakat dengan cara mengetahui ciri atau suatu kebiasaan yang menunjukkan kekhasan kelompok masyarakat tertentu. Dalam penelitian ini, data atau kutipan dalam cerita pendek yang menunjukkan adanya identitas sosial dari suatu individu dalam masyarakat yaitu terdapat cerpen yang berjudul Penjung.

"Kamu harus bisa menempatkan diri dari mana kamu berada," Maskarib bicara dengan menekan suaranya.

Beberapa saat kemudian Maskarib kembali mengatakan, "Ahwiyani itu tamu saya. Ia seorang tandak. Bukan pelacur. Tidak pantas kau berlaku seperti itu padanya. Sebagai tuan rumah, wajib bagi saya menjaga kehormatan dia. Ingat itu!" (Muttaqin, 2019: $4)$.

Penggalan cerita pendek tersebut bercerita tentang Maskarib selaku tuan rumah (yang mengundang tandak) untuk memperingatkan Maksan yang bertingkah kelewatan saat berjoget bersama dengan seorang tandak (penari) bernama Ahwiyani.
Di dalam kelompok masyarakat yang hidup pada latar pada cerpen Penjung, jelas perbuatan atau tindakan yang dilakukan oleh Maksan adalah sebuah pelanggaran atau kesalahan yang berat. Seorang Tandak yang diundang pada pesta pernikahan adalah tanggung jawab tuan rumah yang mengundangnya. Maka dari itu, perbuatan Maksan tersebut merupakan suatu ketidakbenaran yang dilakukan terhadap tandak tersebut khususnya, karena merupakan tindakan tidak terpuji yang dilakukan, kemudian perbuatan yang dilakukan Maksan juga merupakan tindakan yang memancing kekesalan bagi tuan rumah, selaku yang mengundang tandak. Karena perbuatan Maksan tersebut, tuan rumah merasa tidak dihargai dan dihormati oleh tindakan yang dilakukan oleh Maksan tersebut.

Maksan juga terlampau kelewatan dengan mencium pipi Ahwiyani. Identitas seorang Tandak hanya sebatas menari dan melemparkan penjung (selendang tari) untuk mengajak penonton ikut menari bersamanya di panggung, kemudian si penonton yang dipilih dengan cara mengalungkan penjung tersebut haruslah memberikan uang saweran dan bisa ikut menari bersamanya.

Selain itu, hubungan antarkelompok yang terjadi pada peristiwa menjelaskan bahwa Maskarib selaku tuan rumah adalah sosok bajing yang paling ditakuti, dan Maksan merupakan orang yang ada di bawah struktur Maskarib. Sebetulnya dengan struktur tersebut, Maskarib bisa saja dengan mudah menghukum Maksan saat itu juga. Namun demi menjaga ketenangan, Maskarib menahan itu dan lebih menjaga agar tidak terjadi keributan pada peristiwa itu terjadi.

Penjelasan tentang struktur sosial pada kutipan cerpen tersebut sesuai dengan penjelasan yang dikemukakan oleh Giddens bahwa struktur sosial atau yang bisa juga disebut kategori sosial yaitu landasan berperilaku bagi seseorang pada proses identitas hubungan antarkelompoknya. 
Tindakan Maskarib terhadap Maksan dan juga kesalahan yang dibuat Maksan bahwasanya pada kondisi masyarakat yang ditinggalinya tersebut tidak boleh untuk dapat memperlakukan seorang penari dengan semena-mena. Tindakan yang dilakukan Maksan tersebut merupakan sebuah kesalahan atas apa yang sudah terstruktur dalam masyarakat tersebut. Dari tindakan tersbut, sudah menjelaskan bagaimana keadaan struktur atau kategori sosialnya yang terjadi pada cerita pendek berjudul penjung itu.

\section{Tingkah Laku Sosial}

Tingkah laku sosial atau bisa disebut juga komponen budaya merupakan golongan seseorang yang sudah sudah terpahat atau tertanam pada suatu masyarakat tertentu dan praktiknya telah berlangsung dari lama dengan cara terus-menerus atau berkelanjutan. Tingkah laku sosial ini dipandang sebagai penilaian seseorang tentang tingkah lakunya, apakah sesuai dengan norma kelompoknya atau tidak (Giddens, 1991). Tingkah laku sosial ini menjadi sebuah pemakluman yang harus diterima, karena memang sudah disepakati dan dilakukan secara terus-menerus oleh suatu kelompok tertentu. Dalam penelitian ini, data atau kutipan dalam cerita pendek yang menunjukkan adanya unsur tingkah laku sosial yaitu pada cerpen yang berjudul Bulan Celurit.

"Ah, kau tak perlu sekolah tinggi-tinggi. Teman-temanmu di kampung ini sudah pada menikah semua, bahkan ada yang sudah punya anak. Untuk apa kau sekolah tinggitinggi? Toh pada akhirnya kamu juga di dapur," Ibu memegangi tanganku yang mulai dingin (Muttaqin, 2019: 30).

Pada penggalan cerita pendek tersebut, tokoh $A k u$ dilarang untuk melanjutkan sekolahnya ke tingkatan yang lebih tinggi oleh bapaknya. Tindakan yang dilakukan oleh bapaknya ini merupakan sebuah kebiasaan yang sudah dianggap sebagai hal yang normal atau wajar yang sudah diterapkan dalam waktu lama dan terusmenerus oleh kelompok masyarakat di lingkungannya. Latar tempat dalam cerpen ini menjelaskan bahwa perempuanperempuan di kampungnya sudah dinikahkan saat umur mereka sudah memasuki 17-18 tahun (Muttaqin, 2019).

Tindakan yang dilakukan oleh Bapak terhadap tokoh $A k u$ pada cerita pendek tersebut menggambarkan perilaku atau perbuatan yang harus terus diterapkan sesuai dengan kondisi lingkungan yang sudah diterima sejak lama dan dilakukan secara terus-menerus diterapkan oleh kelompok dalam masyarakat pada cerita pendek tersebut.

Pada kasus dalam cerita pendek berjudul Bulan Celurit ini adalah dengan menikahkan anak perempuannya saat masuk usia 17-18 tahun, sesuai dengan tingkah laku dan praktik yang dilakukan oleh kelompok masyarakatnya secara terus-menerus. Bapak dari tokoh $A k u$ ini seolah menerapkan atau menjalankan komponen budaya karena melakukan tingkah laku sosial yang sesuai dengan norma kelompoknya atau tidak sehingga menjadi komponen budaya yang sudah berlangsung terus menerus (Giddens, 1991).

Selain itu, tokoh $A k u$ juga mendapatkan perlakuan ketidakadilan gender berupa subordinasi, karena keputusannya untuk melanjutkan pendidikan dianggap tidak perlu dan tidak penting oleh bapaknya, sehingga menyebabkan pandangan yang kurang menempatkan posisi perempuan untuk bisa mengembangkan dirinya (Fakih, 2013).

\section{Definisi Ontologis}

Definisi ontologis dapat juga disebut sebagai label atau penandaan. Definisi ontologis ini berusaha mengungkapkan seseorang melalui nilai alamiah (hakikat alami) dari individu yang dikategorikan 
berdasarkan kelompok yang terdapat pada masyarakatnya. Label ini muncul dari pernyataan mendasar bahwasanya memang itulah dia (individu), dan tidak bisa disangkal karena memang identitas tersebut telah melekat ke dalam dirinya (individu tersebut) (Giddens, 1991). Data penelitian yang menunjukkan adanya label atau definisi ontologis salah satunya terdapat pada cerpen Gadis Sangkal.

Tapi, Sitti merasa peringatan ibunya seperti tidak masuk akal. Lebih-lebih, Sitti seorang mahasiswi di sebuah universitas swasta. Bagi Sitti, ibunya terlalu primitif, percaya pada hal-hal tidak logis. Apa mungkin seorang gadis tak akan laku selamanya jika menolak pria yang melamarnya pertama kali? Sitti hanya menyimpan pertanyaan itu dalam lubuk hatinya (Muttaqin, 2019: 61).

Kutipan pada cerpen itu menggambarkan tentang karakteristik dari ibu dari tokoh Sitti. Ibu yang digambarkan dalam cerpen tersebut yaitu sosok orang tua yang sangat percaya dengan adanya hal-hal tahayul ataupun halhal yang tidak logis, seperti mitos tentang sangkal. Sangkal merupakan istilah yang diadopsi dari bahasa Jawa Kuno sengkala (sengkolo). Sangkal yang dimaksudkan oleh orang Madura (Sumenep khususnya) yaitu ketika ada orang tua memiliki anak gadis kemudian dilamar atau dipersunting oleh laki-laki, maka tidak boleh ada penolakan karena akan membuat gadis tersebut bisa menjadi sangkal atau tidak akan laku selamanya (Muttaqin, 2019: 58).

Ibu dalam cerpen ini seakan betul-betul mempercayai akan hal tersebut, karena merupakan kepercayaan masyarakat yang sudah mengakar dan dilakukan terusmenerus sehingga menjadi sebuah dalil yang harus dipegang teguh dalam kehidupannya. Pemikiran ibu dalam hal sangkal memang sangat wajar dan mengalir begitu saja karena merupakan sifat alamiah yang dimiliki oleh kelompok masyarakat yang mempercayai akan hal tersebut. Pada kasus dalam cerita pendek ini, tokoh ibu mau tidak mau tidak akan membiarkan anak gadisnya menjadi sangkal karena menolak lamaran pertama dari laki-laki.

Karakter dan perilaku dari tokoh ibu tersebut merupakan label atau hakikat alamiah dari seorang tokoh 'ibu' karena digambarkan sesuai dengan pemikiran dan gagasan yang telah lama mengakar di masyarakat yang menimbulkan stigma bahwa memang seperti itulah kelompok masyarakat tersebut memegang teguh prinsip dan nilai hidupnya. Sangkal dan tokoh ibu merupakan bentuk penjabaran dari hakikat hidup (ontologis) yang menjelaskan bahwa label ini muncul dari pernyataan mendasar bahwasanya memang itulah dia (individu), dan tidak bisa disangkal karena memang identitas tersebut telah melekat ke dalam dirinya (individu tersebut) (Giddens, 1991).

\section{Kearifan Lokal dalam Kumpulan Cerita Pendek Celurit Hujan Panas karya Zainul Muttaqin}

Kearifan lokal yang terkandung dalam kumpulan cerpen Celurit Hujan Panas karya Zainul Muttaqin merupakan sebuah refleksi atau perilaku yang ditunjukkan oleh tokohtokoh yang berlatarkan kehidupan masyarakat Madura dan juga budaya yang terkandungnya. Kearifan lokal ini berupa tindakan yang masih dipraktikkan dalam kehidupan sehari-hari dan pada waktu-waktu tertentu.

Dalam penelitian ini, kearifan lokal yang terkandung dalam kumpulan cerita pendek Bukan Permaisuri antara lain terdiri dari (1) nilai budaya, (2) kepercayaan, serta (3) nilai sosial.

\section{Nilai Budaya}

Nilai budaya merupakan segenap sistem gagasan, perilaku, dan hasil karya dari manusia dalam pemenuhan kehidupan dengan cara belajar yang semuanya sudah berpola dan tersusun dalam kehidupan bermasyarakat (Sujarwa, 2005). Wujud yang 
terkandung dalam kebudayaan ini dapat berupa ide, aktivitas, dan juga artefak. Dalam kumpulan cerita pendek Celurit Hujan Panas ini nilai budaya yang sangat kental yaitu perjodohan dan perilaku mempertahankan martabat atau harga diri dari seorang laki-laki dengan melaksanakan 'carok'.

Dalam penelitian ini, data atau kutipan dalam cerita pendek yang menunjukkan adanya nilai budaya, salah satunya ada pada cerita pendek berjudul Bulan Celurit, cerita pendek berjudul Cinta di Ujung Celurit dan cerita pendek berjudul Celurit yang Dikeramatkan.

Itulah dulu, sebelum akhirnya aku benarbenar dipersunting oleh lelaki pilihan Ibu. Lelaki itu masih ada hubungan kerabat dengan keluargaku. Itulah juga salah satu alasan kenapa Ibu dan Bapak ingin aku segera menikah. Mereka takut hubungan kekeluargaan antara Madrawi dan Bapak terputus begitu saja (Muttaqin, 2019: 30).

"Kenapa Ibu lakukan itu padaku? Aku bisa memilih pendamping hidup sendiri kan, Bu?" Aku merajuk.

"Dengan begitu, kekerabatan kita degan keluarganya Mahwiyah tak akan pernah putus. Juga takut kalau-kalau kau tak laku, Nak.” (Muttaqin, 2019: 40).

Dua kutipan dari penggalan dua cerpen yang berbeda itu menggambarkan tentang perjodohan yang dilaksanakan oleh orang tua kepada anak gadisnya. Dalam kehidupan masyarakat Madura, praktik perjodohan memang sudah menjadi nilai budaya tersendiri yang sudah lama terbentuk dan juga masih sering dipraktikkan. Praktik perjodohan ini dilakukan untuk mengikat anak gadis dan laki-laki dari kedua keluarga besar yang nantinya akan menjalin kekerabatan dan juga persaudaraan hingga nanti dan seterusnya.

Tindakan perjodohan ini bisa dapat dilaksanakan kapan saja, asalkan kedua orang tua dari kedua mempelai sepakat untuk menjodohkan anaknya, karena itulah biasanya tidak memerlukan persetujuan dari kedua mempelai yang nantinya akan dinikahkan, karena memang perjodohan dapat dilakukan hanya dengan melalui persetujuan dari dua keluarga yang terlibat perjodohan tersebut untuk bisa melaksanakan proses perjodohan (Mardhatillah, 2014). Perjodohan yang dilakukan pada cerita pendek tersebut mempunyai tujuan atau alasan yang berupaya untuk mempererat dua keluarga besar agar terus terjaga.

Perjodohan yang dilakukan pada cerita pendek tersebut tidak hanya ketika anak gadis sudah berusia matang dan siap menikah, bahkan pada cerita pendek berjudul Cinta di Ujung Celurit proses atau praktik menjodohkan yang dilakukan antarorang tua dari dua keluarga tersebut sudah dimulai sejak masa kehamilan atau saat kedua calon mempelai belum dilahirkan. Suatu hal yang memang sulit diterima oleh kebiasaan masyarakat modern, namun masih terjadi praktiknya seperti yang digambarkan dalam cerita pendek tersebut.

Budaya perjodohan ini di satu sisi menimbulkan dampak baik karena dari kedua keluarga sudah saling mengetahui baik dan buruk dari masing-masing keluarganya. Namun di lain sisi, perjodohan juga menjadikan perempuan seakan dikungkung karena tidak dapat menikah bersama dengan laki-laki yang dicintainya.

Selain praktik perjodohan yang menjadi nilai budaya khas di masyarakat Madura, nilai budaya yang paling terkenal pada masyarakat Madura adalah carok. Perhatikan kutipan cerita pendek berikut.

"Sukib mengganggumu. Itu artinya penghinaan bagiku. Bagi lelaki di kampung sini, mengganggu istri orang sama saja melecehkan harga diri seorang suami. Dan ketika hal itu terjadi tidak ada tawar-menawar kecuali carok!" Sarkawi menembakkan matanya pada mara istrinya 
yang kelihatan keruh (Muttaqin, 2019: 49).

Penggalan cerita pendek tersebut menggambarkan bahwa carok merupakan bentuk mempertahankan harga diri dan martabat dari seorang lelaki Madura. Carok merupakan bentuk budaya yang sudah lama dilakukan oleh lelaki Madura dalam menyelesaikan masalahnya.

Pada cerita pendek Celurit yang Dikeramatkan, penyebab carok adalah ketika tindakan gangguan dari lelaki lain kepada seorang istri. Sebagai suami yang mempunyai harga diri, tindakan laki-laki lain tersebut menyulut tantangan dan merendahkan si suami tersebut. Carok adalah kegiatan berupa perkelahian antara dua orang laki-laki dari dua keluarga yang berbeda yang dilakukan atas dasar mempertahankan harga diri. Harga diri yang dimaksud biasanya adalah yang termasuk dalam harta, tahta, dan wanita, serta nama baik keluarga besar (Zulkarnain \& et All., 2012).

Carok bukan semata-mata dilakukan atas dasar ingin membunuh, melukai, atau ajang adu kekuatan serta kesaktian dengan orang lain. Orang-orang Madura akan berani mempertaruhkan nyawanya dan pantang mundur apalagi bagi seorang lelaki yang istrinya mendapat gangguan dari lelaki lain. Bagi orang Madura, tindakan menggoda istri orang sama dengan melecehkan martabat suami. Dengan kata lain, carok adalah simbol mempertahankan martabat yang berkaitan dengan kedudukan (Mardhatillah, 2014).

Perjodohan dan carok merupakan bentuk kekayaan dari nilai budaya yang ada, nilai-nilai ini berupa segenap sistem gagasan, perilaku, dan hasil dari karya manusia dalam pemenuhan kehidupan dengan cara belajar yang semuanya sudah berpola dan tersusun dalam kehidupan bermasyarakat dari masyakarat Madura.

\section{Kepercayaan}

Kepercayaan merupakan sebuah unsur yang terdiri dari mitos, mantra, dan juga kepercayaan agama tertentu. Kepercayaan merupakan sebuah pedoman atau kaidah atau konsep spiritual yang dipercaya oleh individu atau kelompok masyarakat tertentu. Keyakinan terhadap kepercayaan yang ada ini dapat berfungsi menjadi suatu acuan (dalil) serta tata norma atau aturan yang diwariskan serta secara turun-temurun dalam waktu yang relatif lama dan tetap diamalkan atau dijalankan oleh suatu kelompok masyarakat tertentu (Hasanuddin, 2015).

Dalam penelitian ini, data atau kutipan dalam cerita pendek yang menunjukkan adanya nilai kepercayaan salah satunya terdapat pada cerita pendek yang berjudul Lelaki Ojung.

Dengan tegas Pak Lurah mengumumkan akan digelar ojung besok sore di lapangan. Ritual ini dipercaya dapat memanggil hujan (Muttaqin, 2019: 76).

Pada penggalan cerita pendek di atas menjelaskan tentang kepercayaan orangorang tentang ritual untuk pemanggilan hujan yang dilakukan melalui kegiatan ojung. Ojung sendiri merupakan tradisi memanggil hujan yang dilakukan masyarakat Madura. Tradisi ini dilakukan oleh dua orang laki-laki dengan cara bertelanjang dada dan silih berganti beradu tubuh (bergulat) dengan bersenjata cambuk yang terbuat dari rotan. Ritual ini dipercaya dapat menurunkan hujan (Muttaqin, 2019: 43).

Dalam pelaksanaannya, ojung juga memiliki mantra yang sudah diwariskan secara turun temurun dan harus dirapalkan (dibacakan seperti doa) oleh orang 'pemain' ketika pelaksanaannya (Maknuna et al., 2013). Ojung juga merupakan bentuk kegiatan yang dipercaya oleh orang Madura ketika hujan tidak lama turun di daerah mereka. Kepercayaan terhadap ojung ini sudah melekat lama dan turun-temurun 
seperti dalil atau acuan dalam menghadapi sebuah persoalan yang ada. Kepercayaan tersebut seperti yang digambarkan pada cerita pendek yang berjudul Lelaki Ojung.

\section{Nilai Sosial}

Nilai sosial dalam kearifan lokal berartikan juga sebuah ungkapan yang terlontar dalam bentuk bahasa daerah berupa falsafah (kata-kata bijak), nasihat, cerita lisan, pepatah, dan sebagainya yang masih berlaku serta dilestarikan turun-temurun dalam suatu daerah tertentu (Hiryanto \& Fathiyah, 2013).

Nilai sosial berupa bahasa ini banyak dijumpai dalam kumpulan cerita pendek Celurit Hujan Panas karya Zainul Muttaqin berupa kata-kata spontan yang menggunakan bahasa Madura atau pun juga pepatah yang keluar dalam bahasa Madura.

Dalam penelitian ini, data atau kutipan dalam cerita pendek yang menunjukkan adanya nilai sosial terdapat pada cerita pendek yang berjudul Kutukan Tanah Leluhur.

"Aku tak mau menjual tanah itu, karena ajhege nak poto bhudi are," Maksan menekan suaranya, terlampau kesal (Muttaqin, 2019: 128).

Kutipan singkat tersebut menjelaskan bahwa Maksan yang kesal karena permintaan istrinya untuk menjual tanah warisan leluhurnya yang ada di tepi pantai. Alasan Maksan tidak mau menjual tanahnya tersebut adalah untuk "menjaga anak cucu di kemudian hari" seperti arti dari dialog Maksan yang menggunakan bahasa Madura.

Nilai sosial berupa bahasa yang mengandung nasehat mendalam ini dipertahankan Maksan demi menjaga anak cucunya nanti di kemudian hari. Maksan mempunyai pemikiran bahwa uang akan habis ketika digunakan terus-menerus, namun ketika mempertahankan tanah, tanah tersebut akan terus bermanfaat untuk kehidupan penerus-penerusnya di kemudian hari.

\section{Hasil Analisis}

Kumpulan cerita pendek Celurit Hujan Panas karya Zainul Muttaqin merupakan sebuah khazanah kesusastraan yang membahas tentang sosial budaya yang khas dari masyarakat Madura. Cerita pendek yang ada pada buku kumpulan cerpen ini merupakan bentuk refleksi atau penggambaran tentang kehidupan masyarakat yang ada di Madura tersebut.

Hasil pencarian data menunjukkan bahwa unsur terbanyak yang terdapat pada identitas sosial dalam kumpulan cerpen ini yaitu 'Tingkah Laku Sosial' sebanyak 12 data. Data-data tersebut menunjukkan bahwa masyarakat Madura mempunyai tingkah laku sosial yang tak dapat dilepaskan pada kehidupan sehari-hari serta dalam kehidupan bermasyarakat dengan kelompoknya. Selain itu, hal ini menggambarkan bahwa tingkah laku sosial menjadi sebuah kekhasan tersendiri yang ditonjolkan oleh masyarakat yang terdapat dalam kumpulan cerpen ini.

Kumpulan cerita pendek Celurit Hujan Panas karya Zainul Muttaqin juga menjadi penanda atau bukti dari suatu kearifan lokal yang masih terkandung dan juga dipraktikkan oleh masyarakat Madura. 'Kepercayaan' merupakan unsur terbanyak dari kearifan lokal dengan 9 data. Unsurunsur tersebut menandakan bahwa masyarakat yang ada dalam kumpulan cerita pendek Celurit Hujan Panas karya Zainul Muttaqin masih memegang teguh ajaran leluhurnya dan masih meyakini bahwa nilainilai yang sudah diwariskan leluhurnya sejak dalam waktu yang lama adalah sebuah nilai atau normal atau tatanan yang harus terus dipegang erat dan dilestarikan dalam praktik kehidupan sehari-hari. Unsur kepercayaan seperti mitos, mantra, agama yang terdapat dalam kumpulan cerita pendek Celurit Hujan Panas karya Zainul Muttaqin masih 
terjaga dan sering dipraktikkan oleh masyarakatnya.

\section{PENUTUP}

Berdasarkan pembahasan dan hasil analisis yang dilakukan terhadap kumpulan cerpen Celurit Hujan Panas karya Zainul Muttaqin ditemukan data yang mengandung unsur identitas sosial dan kearifan yang terkandung dalam peristiwa dari cerpencerpen yang mengandungnya. Identitas sosial yang ada pada karya tersebut menggambarkan tentang kekuatan dan kekhasan dari kelompok masyarakat yang ada di daerah Madura. Selain itu kearifan lokal yang ditemukan pada cerpen-cerpen yang mengandungnya merupakan kekhasan dari daerah Madura yang jarang dan bahkan ditemui di tempat lain.

\section{DAFTAR PUSTAKA}

Ahmad, R. (2020). ANTROPOLOGI SASTRA DALAM CERITA RAKYAT GADIS BERMATA BIRU DAN TOLIRE MA GAM JAHA [Literature Anthropology in Gadis Bermata Biru and Tolire Ma Gam Jaha]. TOTOBUANG, 8(2), 195-207. https://doi.org/10.26499/TTBNG.V8I2. 183

Ashmore, R. D., Jussim, L., \& David, W. (2001). Sosial Identity, Intergroup Conflict, dan Conflict Reduction. Oxford University Press.

Coleman, S., \& Watson, H. (2005). Pengantar Antropologi. Penerbit Nuansa.

Doise, W. (1998). Social Representation in Personal Identity. Sage Publication.

Fakih, M. (2013). Analisis Gender dan Transformasi Sosial. Pustaka Pelajar.

Farida, N., \& Andalas, E. F. (2019). Eksistensi Kearifan Lokal Madura di Era Modern dalam Celurit Hujan Panas Karya Zainul Muttaqin. Atavisme, 22(2).
Faruk. (2005). Pengantar Sosiologi Sastra. Pustaka Pelajar.

Faruk. (2012). Metode Penelitian Sastra. Pustaka Pelajar.

Giddens, A. (1991). Modernity dan SelfIdentity: Self dan Society in the Late Modern Age. Stanford University Press.

Hasanuddin, W. S. (2015). Kearifan Lokal dalam Tradisi Lisan Kepercayaan Rakyat Ungkapan Larangan Tentang Kehamilan, Masa Bayi, dan KanakKanak Masyarakat Minangkabau Wilayah Adat Luhak Nan Tigo. KEMBARA: Jurnal Keilmuan Bahasa, Sastra, Dan Pengajarannya, 1(2), 198204.

Hiryanto, \& Fathiyah, K. N. (2013). Identifikasi Kearifan Lokal dalam Memahami Tanda-Tanda Bencana Alam pada Insan Usia Lanjut di Daerah Istimewa Yogyakarta. Media Informasi Penelitian Kesejahteraan Sosial, 453462.

Hogg, M. A., \& Abrams, D. (1988). Social Identification. Routledge.

Jannah, M. (2019). SENASBASA (Seminar Nasional Bahasa dan Sastra. Prosiding Seminar Nasional Bahasa Dan Sastra Indonesia (SENASBASA), 3(2). http://researchreport.umm.ac.id/index.php/

Jari, D. (2016). Cara Mudah Belajar dan Mengajarkan Sastra. Laksita Indonesia.

Kasmi, H. (2019). Nilai-nilai Kearifan Lokal dalam Novel Tempat Paling Sunyi Karya Arafat Nur. Metamorfosa, 7(2).

Maknuna, L. L., Mustamar, S., \& Ningsih, S. (2013). MANTRA DALAM TRADISI PEMANGGIL HUJAN DI SITUBONDO: KAJIAN STRUKTUR, FORMULA, DAN FUNGSI. Publika Budaya, 1(1), 1-15.

Mardhatillah, M. (2014). Perempuan Madura sebagai Simbol Prestise dan Pelaku Tradisi Perjodohan. Musawa, 13(2), 167-178.

Muhammad, D., Sugara, R., \& Rosi. (2018). 
Analisis Penokohan pada Tokoh Wisanggeni secara Analitis Dramatik dalam Cerita Pendek Berjudul "Honor Cerita Pendek" Karya Hasta Indriyana. Parole: Jurnal Pendidikan Bahasa Dan Sastra Indonesia, 1(4).

Muttaqin, Z. (2019). Celurit Hujan Panas. PT. Gramedia Pustaka Utama.

Nawawi. (2017). Kajian Kearifan Lokal. STAIN Press.

Rampan, K. L. (2013). Antologi Apresiasi Sastra Indonesia. Penerbit Narasi.

Ratna, N. K. (2004). Teori, Metode, dan Teknik Penelitian Sastra. Pustaka Pelajar.

Ratna, N. K. (2007). Teori, Metode dan Teknik Penelitian Sastra: dari Strukturalisme hingga Postrukturalisme. Pustaka Pelajar.

Ratna, N. K. (2009). Paradigma Sosiologi Sastra. Pustaka Pelajar.

Ratna, N. K. (2011). Antropologi Sastra: Peranan Unsur-unsur Kebudayaan dalam Proses Kreatif. Pustaka Pelajar.

Sapdiani, \& et al. (2018). Analisis Struktural dan Nilai Moral dalam Cerpen

"Kembang Gunung Kapur" karya Hasta Indriyana. Parole: Jurnal Pendidikan Bahasa Dan Sastra Indonesia, 1(2), 101-114.

Sugiyono. (2011). Metode Penelitian Kuantitatif, Kualitatif, dan $R \& D$. Afabeta.

Sujarwa. (2005). Manusia dan Fenomena Budaya. Pustaka Pelajar.

Sumardjo, J., \& Saini. (1986). Apresiasi Kesusastraan. PT. Gramedia.

Wellek, R., \& Warren, A. (2016). Teori Kesusastraan. PT. Gramedia.

Winarni, R. (2009). Kajian Sastra. Widya Sari Press.

Zulkarnain, I., \& et All. (2021). Sejarah Sumenep. Dinas Kebudayaan Pariwisata Pemuda dan Olahraga Kabupaten Sumenep. 
